\title{
Article \\ Austenitic Stainless Steel as a Catalyst Material for Photo-Fenton Degradation of Organic Dyes
}

\author{
Catalin Croitoru*D, Ionut Claudiu Roata*, Teodor Machedon-Pisu and Arthur Olah
}

Citation: Croitoru, C.; Roata, I.C.; Machedon-Pisu, T.; Olah, A. Austenitic Stainless Steel as a Catalyst Material for Photo-Fenton Degradation of Organic Dyes. Appl. Sci. 2022, 12, 1008. https://doi.org/ 10.3390/app12031008

Academic Editor: David García Fresnadillo

Received: 5 November 2021

Accepted: 16 January 2022

Published: 19 January 2022

Publisher's Note: MDPI stays neutral with regard to jurisdictional claims in published maps and institutional affiliations.

Copyright: (C) 2022 by the authors. Licensee MDPI, Basel, Switzerland. This article is an open access article distributed under the terms and conditions of the Creative Commons Attribution (CC BY) license (https:// creativecommons.org/licenses/by/ $4.0 /)$.

\begin{abstract}
Materials Engineering and Welding Department, Transilvania University of Brasov, Eroilor 29 Blvd., 500039 Brasov, Romania; tmache@unitbv.ro (T.M.-P.); oart@unitbv.ro (A.O.)

* Correspondence: c.croitoru@unitbv.ro (C.C.); ionut.roata@unitbv.ro (I.C.R.)
\end{abstract}

Featured Application: The advanced degradation of organic pollutants aided by visible light could be carried out through the use of austenitic stainless steel (X5CrNi18-10, AISI 304) as a source for iron ions at $\mathrm{pH}$ values close to neutral.

\begin{abstract}
In this paper, a typical austenitic stainless steel was used as a catalyst in the visible photo-Fenton degradation process of two model dyes, methylene blue and methylorange, in the presence of hydrogen peroxide and potassium persulfate as free radical-generating species. The concentration intervals for both peroxide and persulfate were in the range of 333-1667 $\mu \mathrm{g} / \mathrm{L}$. Very high photodecoloration efficiencies have been achieved using peroxide $(>93 \%)$, while moderate ones have been achieved using persulfate $(>75 \%)$ at a $\mathrm{pH}$ value of 6.5 . For methylene blue, the maximum mineralization yield of $74.5 \%$ was achieved using $1665 \mu \mathrm{g} / \mathrm{L}$ of hydrogen peroxide, while methylorange was better mineralized using $999 \mu \mathrm{g} / \mathrm{L}$ of persulfate. The photodegradation of the dye occurred in two distinct steps, which were successfully modeled by the Langmuir-Hinshelwood pseudo-first-order kinetic model. Reaction rate constants k between 0.1 and $4.05 \mathrm{~h}^{-1}$ were observed, comparable to those presented in the reference literature at lower $\mathrm{pH}$ values and higher concentrations of total iron from the aqueous media.
\end{abstract}

Keywords: photo-Fenton; catalyst; stainless steel; photodegradation; organic dyes; wastewaters

\section{Introduction}

The continuous growth of industry-related activities has led to the discharge of persistent and potentially toxic organic compounds into the environment. Organic compounds with aromatic structures, such as most dyes used in the textile and food industry, phenolic compounds, and pesticides, are relatively challenging to remove through conventional adsorption, precipitation, and chemical/biochemical oxidation processes. Most of these "conventional" processes have several drawbacks, such as poor cost efficiencies or mineralization efficiencies [1,2]. They often fail to completely remove organic pollutants, leaving trace amounts that still pose environmental and/or aesthetic concerns.

Advanced oxidation processes (AOPs) such as the Fenton process have been known to have a much more economically efficient upscaling potential and a relatively low environmental impact compared with heterogeneous semiconductor photocatalysis-based AOPs $[3,4]$.

The Fenton process involves the formation of highly reactive nonspecific oxidant radicals, such as hydroxyl, perhydroxyl, superoxide, or sulfate, based on electron transfer between iron ions and a chemical species capable of generating such radicals, among which hydrogen peroxide, peroxide ion-generating substances (percarbonates, perborates), and persulfates are the most widely used. Traditionally, $\mathrm{Fe}^{2+}$ ions catalyze AOPs more efficiently, but $\mathrm{Fe}^{3+}$ ions can be used as well in combination with a chelating agent [5]. Usually, the electron transfer process works better in relatively acidic conditions ( $\mathrm{pH}$ values between 
2 and 4) due to the complex electrochemistry of iron, which can precipitate from solution as hydroxides with a low solubility, thus limiting the ability of iron ion to react with the oxidant [6]. The generation of oxidant radicals in the Fenton process could be efficiently conducted through chemical means alone, by light from the UV and visible domain (the so-called photo-Fenton process variant) [7], by ultrasonic longitudinal waves [8], or through electrochemical means [6].

The formation of the free hydroxyl radical in the homogeneous Fenton variant occurs in a one-step mechanism variant with a water-soluble $\mathrm{Fe}^{2+}$ source and a two-step mechanism with the addition of $\mathrm{Fe}^{3+}$ ions. Heterogeneous Fenton processes, which use zero-valent iron (ZVI) in the metallic form, are very promising due to the iron source's high accessibility and low cost, the high organic pollutant mineralization rates, and facile separation of the iron source from the treated wastewater. Zero-valent iron is a strong reducing agent and has been used in particulate form for the removal of different organic (aromatic compounds) for groundwater remediation in the form of permeable reaction barriers [9] or as a slurry [10]. $\mathrm{ZVI}$ in the form of micropowders with diameters in the range of 50 to $200 \mu \mathrm{m}$ [11] or in the form of nanopowders [12] shows a good reactivity in the presence of $\mathrm{H}_{2} \mathrm{O}_{2}$, meaning it could react with the surface iron to produce $\mathrm{Fe}^{2+}$ and $\mathrm{Fe}^{3+}$ and initiate the Fenton process [13-15]. Several studies have demonstrated that the optimal $\mathrm{pH}$ in the case of ZVI shifts to higher values (4 to 6 ), allowing outstanding degradation efficiencies for organic aromatic compounds [16,17]. However, zero-valent iron in particulate form has a strong tendency to aggregate, limiting its efficiency over time [12]. Additionally, uncontrolled iron leaching can occur, and the recovery and reusability of ZVI particles lead to the overall process having a higher cost [18]. Several supports for ZVI in particulate form, such as activated carbon cloths or zeolites. have been employed [19,20].

Comparatively, considerably fewer approaches have used metallic iron in pure form (i.e., higher than $99.5 \%$ ) in sheets or meshes as catalyst supports for photo-Fenton processes. Solid iron supports generate iron ions in the presence of hydrogen peroxide without the usual drawbacks of particle aggregation [21]. However, the use of these supports poses problems of its own, such as the rapid passivation of the surface, decrease in the mineralization reaction rate, and inactivation of the surface.

This work aims to study the feasibility of the use of a commonly encountered austenitic stainless steel (X5CrNi18-10, AISI 304) as a zero-valent iron source in the photo-Fenton degradation of methylene blue and methylorange dyes in the presence of peroxide and persulfate ions. Austenitic stainless steel has several advantages compared to pure iron, such as a good corrosion resistance, allowing for a low amount of $\mathrm{Fe}^{2+}$ ions being generated (which reduces sludge formation); constant photodegradation rate; and better overall control of the process. Using an iron-rich support, such as stainless steel, could mitigate the issue of ZVI surface passivation, but the use of stainless steel in photo-Fenton processes is not as widely researched compared to the use of ZVI particles [22,23]. Using persulfate ions to degrade oxidant sulfate radicals for the degradation of the two model dyes in the presence of stainless steel as $\mathrm{ZVI}$ at $\mathrm{pH}$ values close to 7 has been identified as a gap in the literature [24,25]. $\mathrm{pH}$ values close to neutral while generating a lower amount of iron ions in the presence of oxidant species could ensure the reuse and prolonged maintenance of the mechanical properties of the substrate. Under these conditions, the photo-Fenton catalyst can be structural steel from the lining or manufacture of a wastewater storage or treatment tank, without adding supplementary particulate or mesh catalysts.

To possibly contribute to future applications of the photo-Fenton process, a comparison between the degradation efficiency and kinetics of the two model dyes was performed for the two source oxidant species, hydrogen peroxide and potassium persulfate. The persulfate-initiated photo-Fenton process has been addressed less often in the reference literature. Additionally, the photo-Fenton process under nearly neutral $\mathrm{pH}$ conditions is a less well-addressed issue associated with solid iron-based catalysts. The novelty of this study, as previously stated, is not related to using custom-made catalysts or "unconventional" oxidant sources, but to documenting the feasibility of the use of stainless steel 
as a photo-Fenton catalyst for various oxidant concentrations. This type of catalyst has been insufficiently well-studied in the reference literature with photo-Fenton processes. Although stainless steel could be considered rather mundane, its wide use, known behaviour in different environments, and the fact that it is a structural material could constitute an advantage over custom-made ZVI sources for upscaling wastewater treatment installations. This upscaling is not possible without knowing the material's behaviour (performance, compositional stability) under different reaction conditions, and it is the aim of this study to contribute to this.

\section{Materials and Methods}

The methylene blue (MB) cationic dye $\left(\mathrm{C}_{16} \mathrm{H}_{18} \mathrm{ClN}_{3} \mathrm{~S}, \mathrm{M}_{\mathrm{w}}=319.85\right)$ and methylorange (MO) anionic dye $\left(\mathrm{C}_{\mathbf{1 4}} \mathrm{H}_{\mathbf{1 4}} \mathrm{N}_{3} \mathrm{NaO}_{3} \mathrm{~S}, \mathrm{M}_{\mathrm{W}}=327.33\right)$ were purchased from Sigma-Aldrich. The austenitic stainless steel (1.4301; X5CrNi18-10, AISI 304) had a nominal weight percent chemical composition of $0.07 \% \mathrm{C}, 1 \% \mathrm{Si}, 1.5 \% \mathrm{Mn}, 18 \% \mathrm{Cr}, 9 \% \mathrm{Ni}$, Fe balance, determined by atomic emission spectroscopy. The microstructure of the steel, as seen in reflexion microscopy mode ( $200 \times$, aqua regia etchant), consists of equiaxed austenite grains with a small amount of d-ferrite at the austenite grain boundaries (Figure 1a). The reagents used in the spectrophotometric determination of the total Fe content-namely, 1,10-phenanthroline (Phen), hydroxylamine, and trisodium citrate-were purchased from Sigma-Aldrich and were of analytical grade. The hydrogen peroxide was used as a 30\% wt. aqueous solution (Chemical Company SA, Iasi, Romania). The potassium persulfate $\left(\mathrm{K}_{2} \mathrm{~S}_{2} \mathrm{O}_{8}\right)$ oxidant of 99.5\% purity was purchased from Sigma-Aldrich and used as a $4 \%$ vol. aqueous solution.
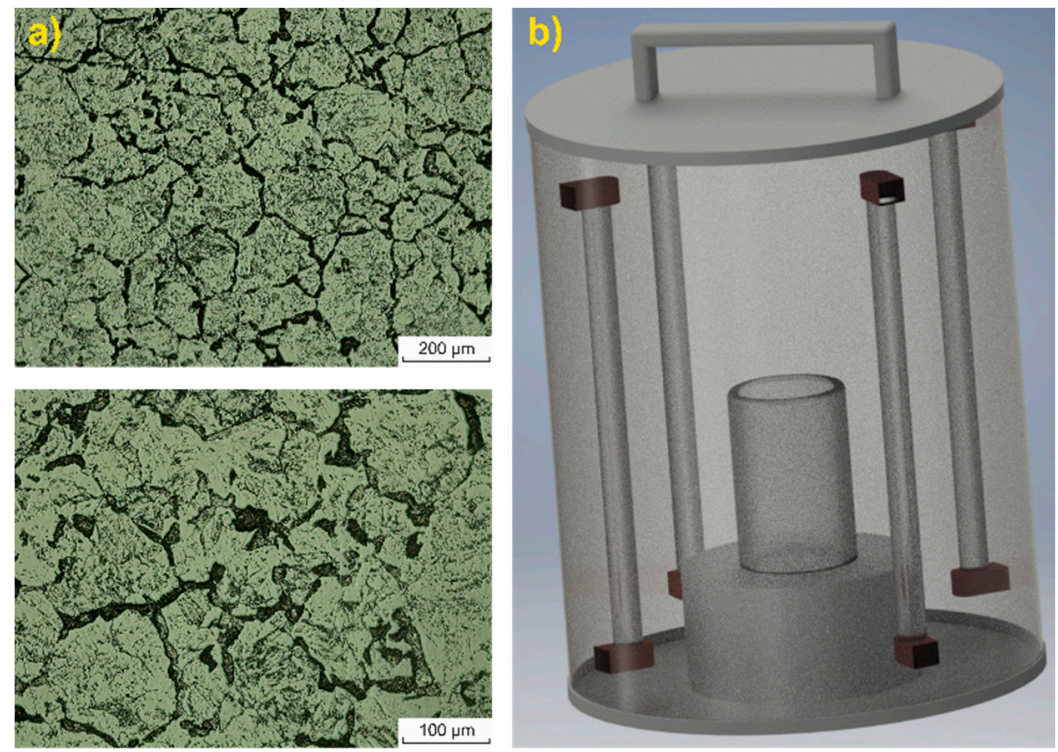

Figure 1. (a): Optical microscopy of the austenitic stainless-steel surface; (b): principle scheme of the photoreactor.

The photodegradation experiments were performed in a closed cylindrical reactor (height $460 \mathrm{~mm}$, diameter $310 \mathrm{~mm}$ ) under irradiation with four visible domain-emitting light bulbs ( $5700 \mathrm{~K}$, wavelength distribution of $\sim 400-750 \mathrm{~nm}$ ) placed annular to the photoreactor (Figure 1b). The steel samples $(20 \mathrm{~mm} \times 20 \mathrm{~mm} \times 8 \mathrm{~mm}$ ) were placed in glass beakers, in contact with $20 \mathrm{~mL}$ of aqueous $\mathrm{MB}$ and MO solutions of $10^{-5} \mathrm{M}$ initial concentration $\left(c_{0}\right)$ at $\mathrm{pH}$ values of $\sim 6.5$ (the typical $\mathrm{pH}$ values of the aqueous dye solutions). The value of the irradiance at the rim of the beaker containing the samples was $1 \mathrm{~mW} / \mathrm{cm}^{2}$. The photodegradation effect was studied with different amounts of added $\mathrm{H}_{2} \mathrm{O}_{2}$ solution to make the concentration of peroxide $333 \mu \mathrm{g} / \mathrm{L}, 666 \mu \mathrm{g} / \mathrm{L}, 999 \mu \mathrm{g} / \mathrm{L}$, and $1665 \mu \mathrm{g} / \mathrm{L}$. In the other batch of experiments, a potassium persulfate starting solution was added to the dye 
solutions so as the initial concentration of $\mathrm{S}_{2} \mathrm{O}_{8}{ }^{2-}$ to reach the same values as in the case of peroxide.

Each experiment was performed at ambient temperature $\left(22{ }^{\circ} \mathrm{C}\right)$ in triplicate; the average values are presented in this paper.

A Spekol 11 mono-channel spectrophotometer (Carl Zeiss Jena, Germany) was used for monitoring the $\mathrm{MB}$ and $\mathrm{MO}$ dye solutions decolorization at various time intervals $\left(\mathrm{c}_{\mathrm{t}}\right)$, based on their absorbance values at wavelength maxima of $\lambda=665 \mathrm{~nm}(\mathrm{MB})$ and $\lambda=465 \mathrm{~nm}$ (MO). The photodegradation efficiencies $(\eta)$ were calculated with Equation (1):

$$
\eta=\frac{c_{0}-c_{t}}{c_{0}} \cdot 100(\%)
$$

In addition, to elucidate the type of radicals responsible for the photodegradation, the photo-Fenton experiments were performed with each of the dye solutions spiked with $50 \mu \mathrm{L}$ tert-butanol $(99.8 \%$, Scharlau), which is an efficient quencher of hydroxyl (HO•) or sulphate $\left(\mathrm{SO}_{4} \cdot{ }^{2-} \bullet\right)$ radicals [25].

To provide a complete picture of the advanced decomposition of $\mathrm{MB}$ and $\mathrm{MO}$, not only based on the degradation of chromophore groups, which determines the VIS absorbance decrease, the chemical oxygen demand (COD) values of the irradiated solutions containing the two dyes were determined using the spectrophotometric method [26]. The COD, expressed in $\mathrm{mg} / \mathrm{L}$, is proportional to the amount of oxidizable organic substances in water [27].

Mineralization was assessed through calculating the COD-based efficiency $\eta_{\mathrm{COD}}$, according to Equation (2):

$$
\eta_{\mathrm{COD}}=\frac{\mathrm{COD}_{0}-\mathrm{COD}_{\mathrm{eq}}}{\mathrm{COD}_{0}} \cdot 100(\%)
$$

where $\mathrm{COD}_{0}$ represents the chemical oxygen demand of the initial dye solutions and $\mathrm{COD}_{\mathrm{eq}}$ represents the equilibrium chemical oxygen demand after reaching the photodegradation equilibrium.

This work aimed to study the performance of the photo-Fenton process under the leastfavorable electrochemical conditions (to preserve the chemical composition of the aqueous environment and the steel as much as possible), with a minimum of added reagents. The average surface roughness $\left(R_{a}\right)$ of the steel was kept as purchased $(1.75 \mu \mathrm{m})$. The monitoring of the total iron content $\left(\mathrm{Fe}^{2+}\right.$ and $\left.\mathrm{Fe}^{3+}\right)$, according to the spectrophotometric method with Phen, was performed at $\lambda=510 \mathrm{~nm}$ according to the procedure described in the reference literature [28].

The surface chemistry of the stainless steel photo-Fenton catalysts after their withdrawal from the irradiated MB dye solutions containing $1665 \mu \mathrm{g} / \mathrm{L}$ hydrogen peroxide and potassium persulfate was assessed through X-ray photoelectron spectrometry (XPS). A Perkin-Elmer (Waltham, MA, USA) XPS PHI 550 spectrometer was used with an Al K $\alpha$ line $(1486.6 \mathrm{eV}) \mathrm{X}$-ray source. Both survey spectra and narrow-scans of Fe2p were acquired using a $20 \mathrm{eV}$ pass energy.

\section{Results and Discussion}

The decolorization of both methylene blue and methylorange dyes was successfully achieved through the use of the stainless steel photocatalyst in the presence of both types of oxidant species-namely, peroxide and persulfate ions.

High photodecoloration efficiencies (>99.1\%) were registered in the case of $\mathrm{MB}$ for all hydrogen peroxide concentrations, indicating that the disruption of the chromophore groups for this dye occurs in a more facile manner than for methylorange, for which efficiencies of $91-93.5 \%$ were registered (Figure 2a,b). As far as photodecoloration is concerned, for the hydrogen peroxide concentration range reported in this paper and under close to neutral $\mathrm{pH}$ conditions, there seems to be a less marked influence of peroxide ion concentration on the photo-Fenton process efficiency for both dyes. 

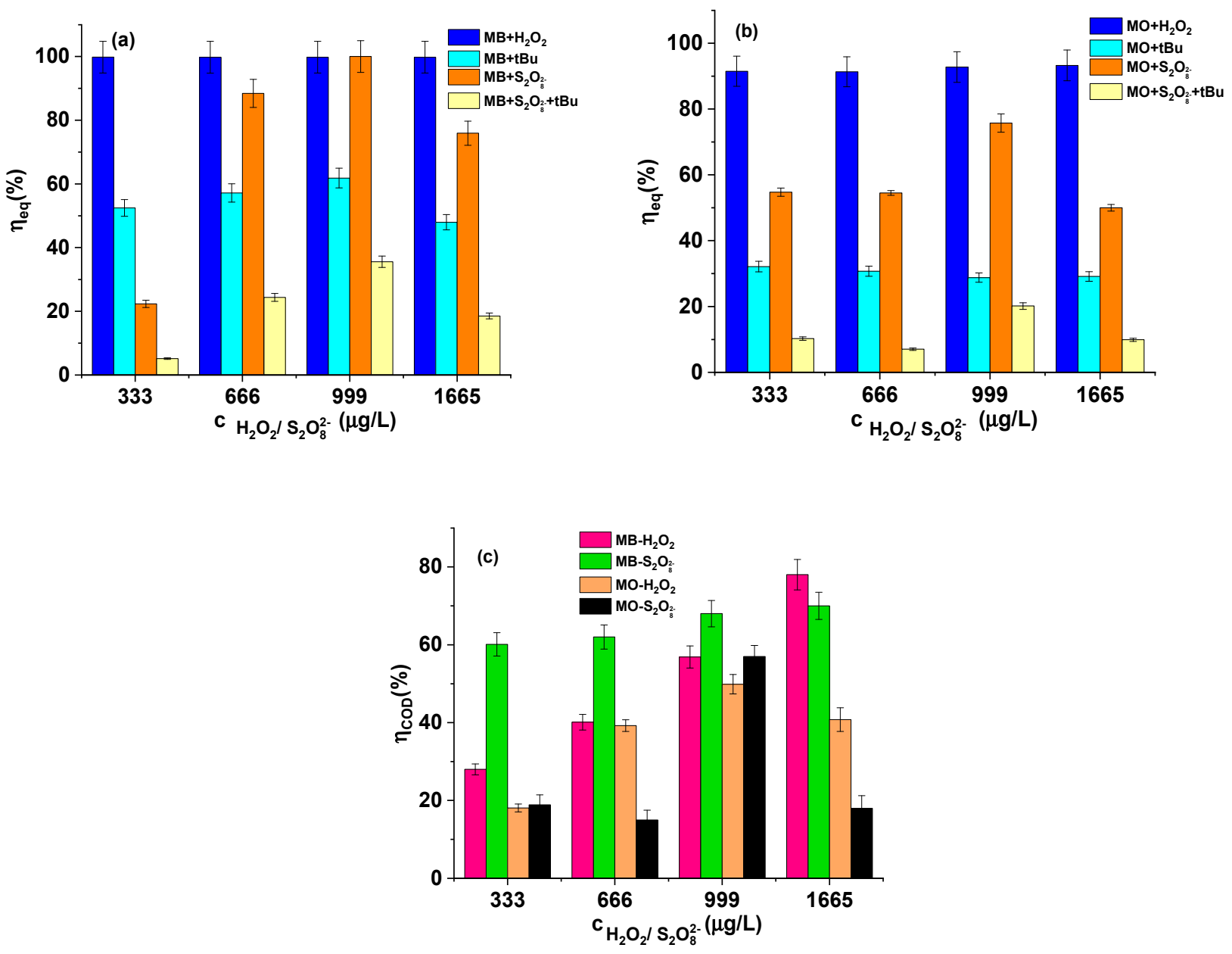

Figure 2. (a): Photodecoloration efficiency for $\mathrm{MB}$ (without and with added tert-butanol scavenger); (b): decolorization efficiency for MO (without and with added tert-butanol scavenger); (c): CODbased mineralization efficiency for MB and MO.

Photodecoloration in the presence of persulfate ions also occurs with a high efficiency in the case of MB $(88.4 \%$ at a $999 \mathrm{mg} / \mathrm{L}$ persulfate concentration, Figure 2a), although in this case, after the aforementioned concentration, there is a sharp efficiency decrease. This could be due to the fact that the higher amount of iron ions generated from stainless steel through persulfate-aided oxidation hinders the efficient harvesting of visible light $[29,30]$.

In the experiments where the photodecoloration occurs in the presence of the sulfate and hydroxyl radicals scavenger tert-butanol (TBu), a decrease of up to $55 \%$ (for $\mathrm{MB}$, Figure $2 \mathrm{a}$ ) and up to $62 \%$ (for MO, Figure $2 \mathrm{~b}$ ) in the photo-Fenton efficiencies was registered for both oxidants, indicating the critical role that these species play in the degradation of organic matter. A more significant drop in photodecoloration efficiency was registered for persulfate due to tert-butanol inhibiting the generation of both sulfate and hydroxyl radicals.

When mineralization comes into discussion, hydrogen peroxide presents the highest photodegradation efficiency for MB (74.5\% vs. $69.9 \%$ for persulfate, at $1666 \mu \mathrm{g} / \mathrm{L}$, Figure $2 \mathrm{c})$, while for MO, persulfate is more efficient at $999 \mu \mathrm{g} / \mathrm{L}$ ( $57 \%$, Figure 2c).

The decolorization kinetic was fitted with the pseudo-first-order kinetic model (Langmuir-Hinshelwood) from Equation (3) [31] and expressed in Figure 3a,b (MB), and Figure $3 \mathrm{c}, \mathrm{d}(\mathrm{MO})$.

$$
\ln \left(\frac{\mathrm{c}_{0}}{\mathrm{c}_{\mathrm{t}}}\right)=\mathrm{kt}
$$



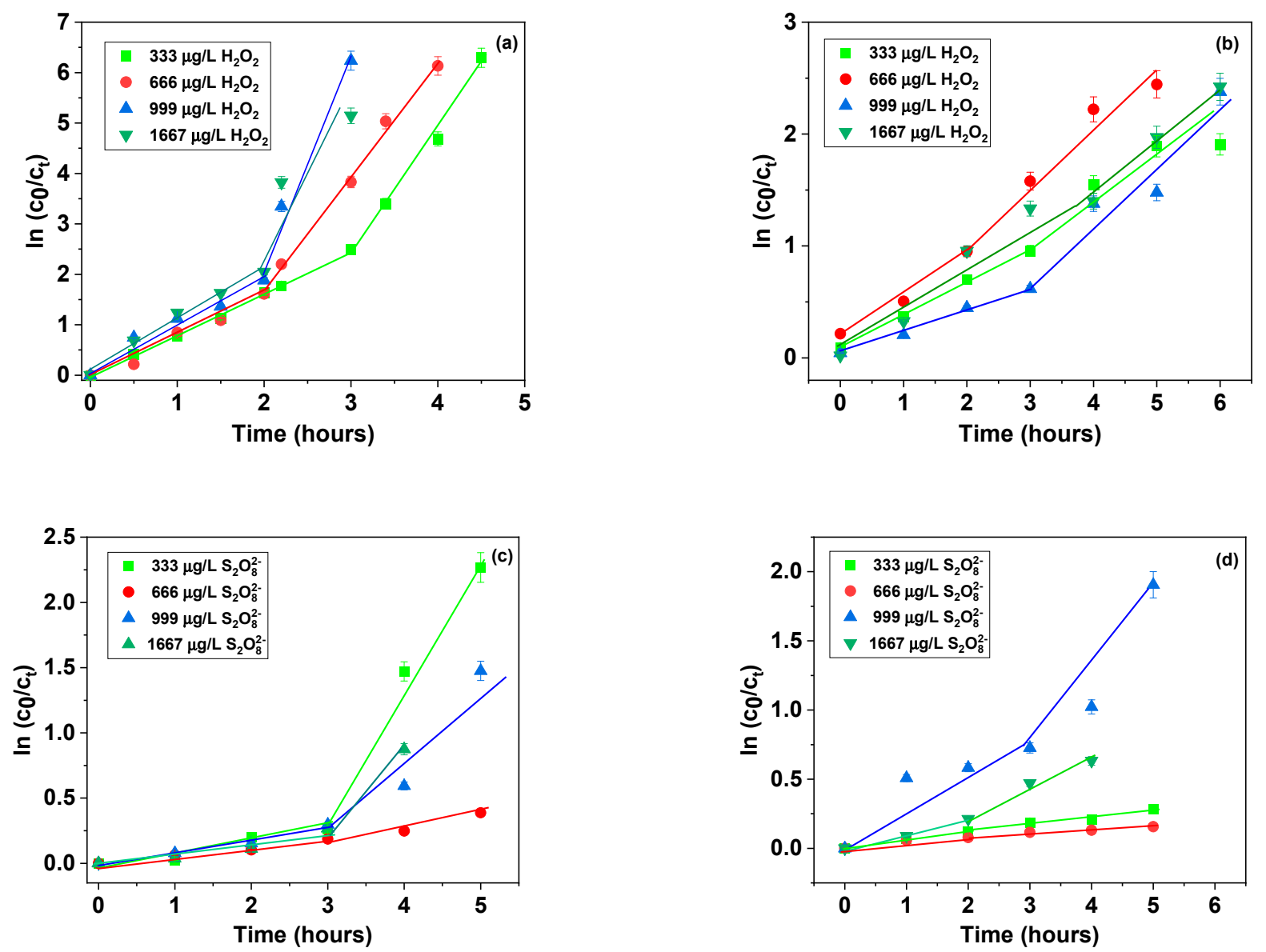

Figure 3. Pseudo-first order kinetic of photodegradation for (a): $\mathrm{MB}$ in the presence of $\mathrm{H}_{2} \mathrm{O}_{2} ;(\mathbf{b})$ : $\mathrm{MO}$ in the presence of $\mathrm{H}_{2} \mathrm{O}_{2} ;(\mathbf{c})$ : $\mathrm{MB}$ in the presence of $\mathrm{S}_{2} \mathrm{O}_{8}{ }^{2-}$; (d): $\mathrm{MO}$ in the presence of $\mathrm{S}_{2} \mathrm{O}_{8}{ }^{2-}$.

In Equation (3), $\mathrm{k}$ represents the pseudo-first-order rate constant. The fitting parameters for this model (including the correlation coefficients, $\mathrm{R}^{2}$ ) are depicted in Tables 1 and 2.

Table 1. Rate constants of the photo-Fenton process as a function of $\mathrm{H}_{2} \mathrm{O}_{2}$ concentration.

\begin{tabular}{|c|c|c|c|c|c|c|}
\hline \multirow{3}{*}{$\begin{array}{c}\mathrm{cH}_{2} \mathrm{O}_{2} \\
(\mu \mathrm{g} / \mathrm{L})\end{array}$} & \multicolumn{3}{|c|}{ Kinetic Data for MB } & \multicolumn{3}{|c|}{ Kinetic Data for MO } \\
\hline & \multirow{2}{*}{$\begin{array}{c}\text { Total Fe } \\
\text { (mg/L) }\end{array}$} & \multicolumn{2}{|c|}{ Rate Constants } & \multirow{2}{*}{$\begin{array}{c}\text { Total Fe } \\
\text { (mg/L) }\end{array}$} & \multicolumn{2}{|c|}{ Rate Constants } \\
\hline & & $k_{1}\left(\mathrm{~h}^{-1}\right)$ & $k_{2}\left(\mathrm{~h}^{-1}\right)$ & & $k_{1}\left(\mathrm{~h}^{-1}\right)$ & $k_{2}\left(\mathrm{~h}^{-1}\right)$ \\
\hline 333 & 0.13 & $0.77(0.992)$ & $2.35(0.995)$ & 0.15 & $0.33(0.962)$ & $0.35(0.983)$ \\
\hline 666 & 0.16 & $1.00(0.987)$ & $2.39(0.998)$ & 0.18 & $0.34(0.996)$ & $0.87(0.980)$ \\
\hline 999 & 0.17 & $1.23(0.985)$ & $3.21(0.996)$ & 0.21 & $0.39(0.993)$ & $1.03(0.984)$ \\
\hline 1665 & 0.28 & $1.26(0.992)$ & $4.05(0.978)$ & 0.32 & $0.47(0.983)$ & $1.33(0.989)$ \\
\hline
\end{tabular}

Table 2. Rate constants of the photo-Fenton process as a function of $\mathrm{S}_{2} \mathrm{O}_{8}{ }^{2-}$ concentration.

\begin{tabular}{|c|c|c|c|c|c|c|}
\hline \multirow{3}{*}{$\begin{array}{c}\mathrm{cS}_{2} \mathrm{O}_{8}{ }^{2} \\
(\mu \mathrm{g} / \mathrm{L})\end{array}$} & \multicolumn{3}{|c|}{ Kinetic Data for MB } & \multicolumn{3}{|c|}{ Kinetic Data for MO } \\
\hline & \multirow{2}{*}{$\begin{array}{c}\text { Total Fe } \\
\text { (mg/L) }\end{array}$} & \multicolumn{2}{|c|}{ Rate Constants } & \multirow{2}{*}{$\begin{array}{c}\text { Total Fe } \\
\text { (mg/L) }\end{array}$} & \multicolumn{2}{|c|}{ Rate Constants } \\
\hline & & $k_{1}\left(\mathrm{~h}^{-1}\right)$ & $k_{2}\left(\mathrm{~h}^{-1}\right)$ & & $k_{1}\left(\mathrm{~h}^{-1}\right)$ & $k_{2}\left(\mathrm{~h}^{-1}\right)$ \\
\hline 333 & 0.94 & $0.35(0.892)$ & $1.36(0.996)$ & 0.98 & $0.20(0.936)$ & $0.35(0.983)$ \\
\hline 666 & 1.36 & $0.10(0.951)$ & $0.38(0.995)$ & 1.32 & $0.23(0.984)$ & $0.36(0.990)$ \\
\hline 999 & 2.96 & $0.15(0.980)$ & $0.24(0.992)$ & 3.04 & $0.10(0.989)$ & $0.33(0.999)$ \\
\hline 1665 & 3.68 & $0.12(0.996)$ & $0.30(0.999)$ & 3.95 & $0.25(0.988)$ & $0.28(0.999)$ \\
\hline
\end{tabular}


Figure 3a-d indicate that the photo-Fenton degradation mechanism of both dyes occurs in two steps. The first part of the kinetic (rate constant, $\mathrm{k}_{1}$ ) is characterized by a slower overall degradation of the dyes for both $\mathrm{H}_{2} \mathrm{O}_{2}$ and $\mathrm{S}_{2} \mathrm{O}_{8}{ }^{2-}$, because in this step the oxidation of metallic iron $\mathrm{Fe}^{0}$ to $\mathrm{Fe}^{2+}$ and the generation of hydroxyl and sulfate radicals take place; thus, initially there is a low amount of oxidant species to initiate the photodegradation. The generation of reactive $\mathrm{HO} \bullet$ radicals in the presence of $\mathrm{H}_{2} \mathrm{O}_{2}$ and $\mathrm{Fe}^{2+}$ ions from the catalyst is depicted by the following Mechanism (4) [32,33]:

$$
\begin{aligned}
& \mathrm{Fe}^{0}+\mathrm{H}_{2} \mathrm{O}_{2} \stackrel{h v}{\rightleftharpoons} \mathrm{Fe}^{2+}+2 \mathrm{OH}^{-} \\
& \mathrm{Fe}^{2+}+\mathrm{H}_{2} \mathrm{O}_{2} \stackrel{h v}{\rightleftharpoons} \mathrm{Fe}^{3+}+\mathrm{OH}^{-}+\mathrm{HO} \bullet \\
& \mathrm{Fe}^{0}+2 \mathrm{Fe}^{3+} \rightleftarrows 3 \mathrm{Fe}^{2+}
\end{aligned}
$$

The persulfate ions can decompose in a first slow, ongoing step to highly reactive sulfate radicals $\left(\mathrm{SO}_{4}{ }^{-} \bullet\right)$, which oxidize the metallic iron to produce $\mathrm{Fe}^{2+}$ ions (i.e., the iron is "activated"), which can further initiate the production of sulfate radicals on their own. Avoiding surface passivation in this step is crucial for achieving a high photodegradation yield [32]. The sulfate radicals can react with water to generate hydroxyl radicals, so for the persulfate oxidant, the dyes can be oxidized by both type of radicals $[29,34,35]$, according to the following Mechanism (5):

$$
\begin{aligned}
& \mathrm{S}_{2} \mathrm{O}_{8}^{2-} \stackrel{h v}{\rightleftharpoons} 2 \mathrm{SO}_{4}^{-} \bullet \\
& 2 \mathrm{SO}_{4}^{-} \bullet+\mathrm{Fe}^{0}+2 \mathrm{H}_{2} \mathrm{O} \stackrel{h v}{\rightleftharpoons} \mathrm{Fe}^{2+}+2 \mathrm{HSO}_{4}^{-}+2 \mathrm{HO}^{-} \\
& \mathrm{Fe}^{2+}+\mathrm{S}_{2} \mathrm{O}_{8}^{2-} \stackrel{h v}{\rightleftharpoons} \mathrm{Fe}^{3+}+\mathrm{SO}_{4}^{-} \bullet+\mathrm{SO}_{4}^{2-} \\
& \mathrm{SO}_{4}^{-} \bullet+\mathrm{H}_{2} \mathrm{O} \stackrel{h v}{\rightleftharpoons} \mathrm{HO} \bullet+\mathrm{HSO}_{4}^{-}
\end{aligned}
$$

Regarding the dye photodegradation in this step, these could be oxidized to higher molecular mass intermediates (possibly hydroxylated compounds or carboxylic acids) according to Mechanism (6), where DyeH denotes the methylene blue/methylorange dyes in their non-oxidized form. The dyes can also be directly oxidized by $\mathrm{Fe}^{3+}$ ions $[35,36]$.

$$
\begin{aligned}
& \mathrm{DyeH}+\mathrm{HO} \bullet \stackrel{h v}{\rightleftharpoons} \text { Dye }+\mathrm{H}_{2} \mathrm{O} \\
& \mathrm{DyeH}+\mathrm{SO}_{4}^{-} \bullet \stackrel{h v}{\rightleftharpoons} \text { Dye } \bullet+\mathrm{HSO}_{4}^{-} \\
& \text {Dye }+\mathrm{Fe}^{3+} \stackrel{\mathrm{Dye}^{+}+\mathrm{Fe}^{2+}}{\rightleftarrows}
\end{aligned}
$$

In the second step, these organic intermediates can be degraded at a higher rate to smaller molecular compounds with a rate constant of $k_{2}$. The values of $k_{1}$ and $k_{2}$ for each amount of $\mathrm{H}_{2} \mathrm{O}_{2}$ and $\mathrm{S}_{2} \mathrm{O}_{8}{ }^{2-}$ added are presented in Tables 1 and 2 (the $\mathrm{R}^{2}$ correlation coefficients are given in parentheses after the actual values of $k_{1}$ and $k_{2}$ ).

For both dyes, the results indicate that the initial peroxide or persulfate ion concentrations play a crucial role in the kinetic of photodecoloration. For hydrogen peroxide (Table 1), there is a linear increase in the reaction rates for both steps until $999 \mu \mathrm{g} / \mathrm{L}(29.38 \mu \mathrm{mol} / \mathrm{L})$, which seems to represent the optimal concentration for the setup presented in the paper. After this optimal hydrogen peroxide concentration value, there is a leveling off in the reaction rate. Excess amounts of $\mathrm{H}_{2} \mathrm{O}_{2}$ could determine the trapping of the generated hydroxyl radicals to form hydroperoxyl radicals (with lower oxidation potential) and water, according to the Mechanism (7). Additionally, a higher amount of generated $\mathrm{Fe}^{2+}$ with the increase in $\mathrm{H}_{2} \mathrm{O}_{2}$ addition could determine the decrease in the concentration of the hydroxyl radicals $[33,37]$.

For persulfate (Table 2), the optimum concentration for photodecoloration is maintained at $999 \mu \mathrm{g} / \mathrm{L}(5.20 \mu \mathrm{mol} / \mathrm{L})$, after which the generated iron ions can similarly quench both sulfate and hydroxyl radicals through the following Mechanism (7): 


$$
\begin{aligned}
& \mathrm{HO} \bullet+\mathrm{H}_{2} \mathrm{O}_{2} \stackrel{h v}{\rightleftharpoons} \mathrm{HO}_{2} \bullet+\mathrm{H}_{2} \mathrm{O} \\
& \mathrm{HO} \bullet+\mathrm{Fe}^{2+} \stackrel{h v}{\rightleftharpoons} \mathrm{HO}^{-}+\mathrm{Fe}^{3+} \\
& \mathrm{SO}_{4}^{-} \bullet+\mathrm{Fe}^{2+} \stackrel{h v}{\rightleftharpoons} \mathrm{SO}_{4}^{2-}+\mathrm{Fe}^{3+}
\end{aligned}
$$

In general, the methylorange-related rate constants are up to $42 \%$ lower than those corresponding to methylene blue due to the higher molecular mass of the former. A similar trend was also observed for semiconductor-aided photocatalysis [38]. Tables 1 and 2 also indicate that the total amount of iron generated in the solution during the photo-Fenton process is below the recommended values for groundwater $(0.3 \mathrm{mg} / \mathrm{L}$, as recommended by the World Health Organization) in the case of using hydrogen peroxide. A higher total iron amount is generated for potassium persulfate, which may need additional precipitation and filtering steps for the wastewater.

A comparison of the overall efficiency of photo-Fenton over the widely available systems reported in the reference literature must be viewed with some caution, due to the different experimental conditions, reagent concentrations, model pollutant concentrations, and catalyst specific surfaces used, but it is widely agreed that fast degradation rate constants (k), coupled with high decoloration and mineralization rates, constitute important candidate parameters. Additionally, the use of the smallest amount of catalyst, iron ions, and oxidant possible is desired for economic efficiency reasons and to limit additional wastewater purification steps and avoid the excessive degradation of the catalyst $[7,39,40]$. In some studies, the importance of the photo-Fenton reaction medium's $\mathrm{pH}$ value being as close to neutral as possible is also stressed [7,41]. For the sake of comparison, to highlight the benefits of using the proposed system with other photo-Fenton setups, Table 3 lists the photo-Fenton process parameters and efficiencies in other studies extracted from the reference literature.

\begin{tabular}{|c|c|c|c|c|c|c|c|}
\hline \multicolumn{8}{|c|}{ Photo-Fenton with Hydrogen Peroxide } \\
\hline Catalyst Type & $\begin{array}{l}\text { Model } \\
\text { Dye(s) }\end{array}$ & $\begin{array}{l}\text { Process } \\
\text { Efficiency }\end{array}$ & $\begin{array}{c}\text { Rate } \\
\text { Constants k }\end{array}$ & $\begin{array}{l}\text { Iron Amount in } \\
\text { Solution }\end{array}$ & $\begin{array}{l}\text { Oxidant } \\
\text { Amount }\end{array}$ & $\mathrm{pH}$ & Reference \\
\hline \multirow{2}{*}{ Stainless steel } & MB & $\begin{array}{c}\text { Discoloration eff.: } \\
\text { max. } 99.5 \% \text {, } \\
\text { mineralization } \\
\text { eff. } 74.5 \%\end{array}$ & $0.77-4.05 \mathrm{~h}^{-1}$ & $0.13-0.28 \mathrm{mg} / \mathrm{L}$ & \multirow{2}{*}{$333-1665 \mu \mathrm{g} / \mathrm{L}$} & \multirow{2}{*}{6.5} & \multirow{2}{*}{ This study } \\
\hline & $\mathrm{MO}$ & $\begin{array}{c}\text { Discoloration eff.: } \\
\text { max. } 93.5 \% \text {, } \\
\text { mineralization } \\
\text { eff. } 49.9 \%\end{array}$ & $0.33-1.33 \mathrm{~h}^{-1}$ & $0.15-0.32 \mathrm{mg} / \mathrm{L}$ & & & \\
\hline $\begin{array}{l}\text { Nano ZVI } \\
\text { particles }\end{array}$ & MB & $\begin{array}{l}\text { Discoloration eff.: } \\
\max .98 \%\end{array}$ & $\max 2.34 \mathrm{~h}^{-1}$ & $150 \mathrm{mg} / \mathrm{L}$ & $3100 \mathrm{mg} / \mathrm{L}$ & 2 & [42] \\
\hline $\mathrm{Fe}-\mathrm{Ni} / \mathrm{SiO}_{2}$ & $\mathrm{MB}$ & $\begin{array}{c}\text { Discoloration eff.: } \\
\text { max. } 99.80 \% \text { at } \\
\text { pH } 3 \\
\text { and } 83 \% \text { at } \mathrm{pH}=9\end{array}$ & n.a. & n.a. & $102 \mathrm{mg} / \mathrm{L}$ & $1.5-11$ & [33] \\
\hline $\begin{array}{l}\mathrm{Au}-\mathrm{Fe}_{3} \mathrm{O}_{4} / \\
\text { graphene }\end{array}$ & MB & $\begin{array}{l}\text { Discoloration eff.: } \\
\text { max. } 99 \%\end{array}$ & n.a. & $\max .0 .6 \mathrm{mg} / \mathrm{L}$ & $0.2-1 \mathrm{~g} / \mathrm{L}$ & 7.2 & [43] \\
\hline $\begin{array}{c}\mathrm{Fe}_{3} \mathrm{O}_{4} \text { and } \\
\alpha-\mathrm{Fe}_{2} \mathrm{O}_{3}\end{array}$ & MB & $\begin{array}{l}\text { Discoloration eff.: } \\
\max .95 \%\end{array}$ & $\max .0 .78 \mathrm{~h}^{-1}$ & n.a. & $300-500 \mathrm{mg} / \mathrm{L}$ & 6.5 & [44] \\
\hline $\begin{array}{c}\text { nitrilotriacetic } \\
\text { acid-bonded } \mathrm{Fe}^{2+}\end{array}$ & MB & $\begin{array}{c}\text { Discoloration eff.: } \\
\text { max. } 97.4 \%\end{array}$ & n.a. & $1-3 \mathrm{mg} / \mathrm{L}$ & $40-100 \mathrm{mg} / \mathrm{L}$ & 6.5 & {$[45]$} \\
\hline
\end{tabular}

Table 3. Parameters of selected photo-Fenton processes from the reference literature compared to those of the present study. 
Table 3. Cont.

\begin{tabular}{|c|c|c|c|c|c|c|c|}
\hline \multicolumn{8}{|c|}{ Photo-Fenton with Hydrogen Peroxide } \\
\hline Catalyst Type & $\begin{array}{l}\text { Model } \\
\text { Dye(s) }\end{array}$ & $\begin{array}{l}\text { Process } \\
\text { Efficiency }\end{array}$ & $\begin{array}{c}\text { Rate } \\
\text { Constants k }\end{array}$ & $\begin{array}{l}\text { Iron Amount in } \\
\text { Solution }\end{array}$ & $\begin{array}{l}\text { Oxidant } \\
\text { Amount }\end{array}$ & $\mathrm{pH}$ & Reference \\
\hline $\begin{array}{c}\text { Fe-Based } \\
\text { Metal-Organic } \\
\text { Frameworks }\end{array}$ & MB & $\begin{array}{l}\text { Discoloration eff.: } \\
\max .99 \%\end{array}$ & n.a. & $100 \mathrm{mg} / \mathrm{L}$ & $735 \mathrm{mg} / \mathrm{L}$ & 6.5 & [46] \\
\hline $\begin{array}{c}\text { FeCu bimetallic } \\
\text { system }\end{array}$ & $\mathrm{MO}$ & $\begin{array}{l}\text { mineralization } \\
\text { eff. } 78 \%\end{array}$ & n.a. & $\max .0 .32 \mathrm{mg} / \mathrm{L}$ & $490 \mathrm{mg} / \mathrm{L}$ & 7 & [47] \\
\hline \multicolumn{8}{|c|}{ Photo-Fenton with persulfate } \\
\hline \multirow{2}{*}{ Stainless steel } & $\mathrm{MB}$ & $\begin{array}{c}\text { Discoloration eff.: } \\
\text { max. } 88.4 \% \text {, } \\
\text { mineralization } \\
\text { eff. } 69.9 \%\end{array}$ & $0.10-1.36 \mathrm{~h}^{-1}$ & $0.94-3.68 \mathrm{mg} / \mathrm{L}$ & \multirow{2}{*}{$333-1665 \mu \mathrm{g} / \mathrm{L}$} & \multirow{2}{*}{6.5} & \multirow{2}{*}{ This study } \\
\hline & $\mathrm{MO}$ & $\begin{array}{c}\text { Discoloration eff.: } \\
\text { max. } 75.7 \%, \\
\text { mineralization } \\
\text { eff. } 57 \%\end{array}$ & $0.10-0.36 \mathrm{~h}^{-1}$ & $0.98-3.95 \mathrm{mg} / \mathrm{L}$ & & & \\
\hline $\begin{array}{c}\mathrm{Fe}^{2+}\left(\mathrm{FeSO}_{4}\right) \\
\text { under UV }\end{array}$ & $\mathrm{MO}$ & $\begin{array}{c}\text { Discoloration eff.: } \\
\text { max. } 99 \% \text { at } \\
\text { pH } 3,2 \% \text { at pH } 7\end{array}$ & $\sim 30 \mathrm{~h}^{-1}$ & $2-20 \mathrm{mg} / \mathrm{L}$ & $50 \mathrm{mg} / \mathrm{L}$ & $3-7$ & [48] \\
\hline $\begin{array}{c}\text { ZVI metallic Fe } \\
\text { nanoparticles }\end{array}$ & $\mathrm{MO}$ & $\begin{array}{c}\text { Discoloration eff.: } \\
\text { max. } 98 \% \text { at } \\
\text { pH } 3,70 \% \text { at } \\
\text { pH } 7\end{array}$ & n.a. & n.a. & $30 \mathrm{mg} / \mathrm{L}$ & $3-7$ & [49] \\
\hline
\end{tabular}

By analysing the data presented in Table 3, it can be seen that using austenitic stainless steel as a photo-Fenton catalyst determines good mineralization and discoloration efficiencies at near-neutral $\mathrm{pH}$ values. Compared with the literature data, attained using hydrogen peroxide or persulfate and $\mathrm{Fe}^{2+}$ salts or ZVI nanoparticles as an iron source, at the same $\mathrm{pH}$ values as used in this study (6-7), the mineralization efficiency can be considered practically nil $[33,42,48,49]$. Comparable degradation efficiencies of already-reported photo-Fenton systems are reported to be achieved only under acidic $\mathrm{pH}$ values (3-4), which generate total iron concentrations in solution ranging from 0.6 to $150 \mathrm{mg} / \mathrm{L}$. Compared to this study, these values are up to 38 times higher, necessitating further separation steps in a real-life wastewater treatment pilot installation. Also, photo-Fenton on solid stainless steel supports, as reported herein, can operate at oxidant concentrations of 20 to 460 times lower than those reported in the reference literature [44,46], reducing the costs and the oxidative degradation of the installation. The reaction rates obtained are similar to those reported in the reference literature for ZVI nanoparticles or iron salts (except when using UV irradiation) but under nearly-neutral $\mathrm{pH}$ conditions. A comparison of this study's reaction rates with those from the reference literature under neutral $\mathrm{pH}$ conditions was not possible due to the lack of such data for MB and MO.

Regarding the surface chemistry of the catalyst, the relative wt.\% of the elements of interest $(\mathrm{Fe}, \mathrm{Cr}, \mathrm{Ni}, \mathrm{C}, \mathrm{O})$ before and after the photo-Fenton degradation process for both hydrogen peroxide and potassium persulfate ions at their highest concentration $(1667 \mu \mathrm{g} / \mathrm{L})$ used in this study was determined through XPS spectroscopy (Figure 4a, Table 4). It can be seen that the most notable modification in the surface chemistry of stainless steel is the increase in oxygen content with $107 \%$ in the case of hydrogen peroxide and with $159 \%$ in the case of potassium persulfate. 

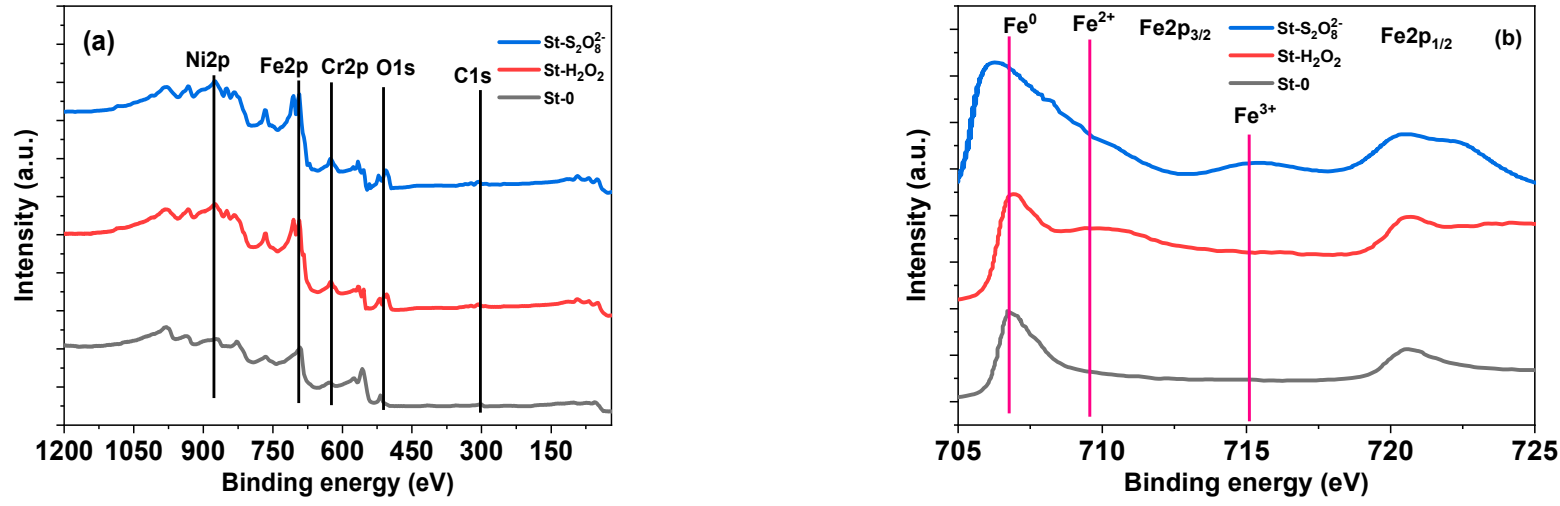

Figure 4. (a): Survey XPS spectra of stainless steel (St-0), stainless steel immersed in hydrogen peroxide $\left(\mathrm{St}-\mathrm{H}_{2} \mathrm{O}_{2}\right)$, and stainless steel immersed in potassium persulfate $\left(\mathrm{St}-\mathrm{S}_{2} \mathrm{O}_{8}{ }^{2-}\right)$; (b): highresolution XPS Fe2p envelopes.

Table 4. Relative surface chemistry of the samples calculated from XPS spectra.

\begin{tabular}{|c|c|c|c|c|c|c|c|}
\hline \multirow{2}{*}{ Sample } & \multicolumn{5}{|c|}{ Relative Element Concentration (wt.\%) } & \multirow{2}{*}{\multicolumn{2}{|c|}{$\begin{array}{c}\text { Fe Chemical Species (2p) } \\
\text { (rel. \%) }\end{array}$}} \\
\hline & $\mathrm{Fe} 2 \mathrm{p}$ & Cr2p & Ni2p & O1s & C1s & & \\
\hline St-0 & 70.48 & 17.9 & 9.54 & 2.02 & 0.06 & $\begin{array}{c}\mathrm{Fe}^{0} \\
\mathrm{Fe}^{2+} \\
\mathrm{Fe}^{3+}\end{array}$ & $\begin{array}{c}98.4 \\
- \\
1.6\end{array}$ \\
\hline St- $\mathrm{H}_{2} \mathrm{O}_{2}$ & 68.47 & 17.8 & 9.50 & 4.19 & 0.04 & $\begin{array}{l}\mathrm{Fe}^{0} \\
\mathrm{Fe}^{2+} \\
\mathrm{Fe}^{3+}\end{array}$ & $\begin{array}{c}90.3 \\
7.3 \\
2.4\end{array}$ \\
\hline St- $\mathrm{S}_{2} \mathrm{O}_{8}{ }^{2-}$ & 67.37 & 17.8 & 9.55 & 5.24 & 0.04 & $\begin{array}{c}\mathrm{Fe}^{0} \\
\mathrm{Fe}^{2+} \\
\mathrm{Fe}^{3+}\end{array}$ & $\begin{array}{c}89.1 \\
7.8 \\
3.1\end{array}$ \\
\hline
\end{tabular}

Furthermore, there is a decrease up to a maximum of $4.5 \%$ in the iron content of the material. An increase in the oxygen content on the steel surface and iron dissolution has also been observed in the case of electro-Fenton processes [22,50]. The dissolved iron provides the ions necessary to initiate and sustain the photo-Fenton photodegradation process. As mentioned in Tables 1 and 2, the iron concentration in solution ranges from 0.13 to $3.95 \mathrm{mg} / \mathrm{L}$. In water, iron concentrations below $0.3 \mathrm{mg} / \mathrm{L}$ can be characterized as unnoticeable, whereas levels of $0.3-3 \mathrm{mg} / \mathrm{L}$ are generally acceptable [26]. As previously stated, using stainless steel at near-neutral $\mathrm{pH}$ generates much less iron in solution than "traditional" processes using ZVI iron (Table 3).

Regarding $\mathrm{Ni}$ and $\mathrm{Cr}$, the other major constituents of stainless steel responsible for its characteristic corrosion resistance in aqueous environments, Table 4 reveals that there is a $0.05 \%$ reduction in the weight percentage of $\mathrm{Ni}$ on the surface of the stainless steel catalyst submitted to the photo-Fenton process $\left(\mathrm{H}_{2} \mathrm{O}_{2}\right.$ oxidant), while for $\mathrm{Cr}$, a reduction of $0.01 \%$ is registered for both oxidants. In solution, at the experimental $\mathrm{pH}$ values used in this study, nickel should exist as $\mathrm{NiO}$ and / or $\mathrm{Ni}(\mathrm{OH})_{2}$, as these species are stable at $\mathrm{pH} 5-15$. Consequently, these species tend to separate from aqueous solution and precipitate [51], posing a low cause for environmental concern. Cr oxidation products such as $\mathrm{Cr}^{3+}$ and/or $\mathrm{Cr}(\mathrm{VI})$ ions are rarely present at $\mathrm{pH}$ values over 6 because hydrated chromium oxide $\left(\mathrm{Cr}(\mathrm{OH})_{3}\right)$ is hardly water-soluble, and $\mathrm{Cr}(\mathrm{VI})$ can be reduced to $\mathrm{Cr}^{3+}$ (thus precipitating it out of the solution) by the $\mathrm{Fe}^{2+}$ ions [52,53]. More probably, since $\mathrm{Ni}$ and $\mathrm{Cr}$ are known to form a thin oxide layer on the surface of stainless steel in the presence of atmospheric oxygen (oxygen is present in the surface chemistry of the steel material, as in Table 4), the reduction in the surface $\mathrm{Ni}$ and $\mathrm{Cr}$ in steel could be more likely due to the microabrasion of this oxide layer than metallic $\mathrm{Ni}$ and $\mathrm{Cr}$ oxidation to water-soluble species [54]. 
Regarding the chemical states of iron (high-resolution Fe2p envelopes, Figure 4b), all samples present a high-intensity broad signal ascribed to metallic $\mathrm{Fe}^{0} 2 \mathrm{p}_{3 / 2}$ at about $706 \mathrm{eV}$, representing the dominating contribution [55]. Fe in higher oxidation states, such as $\mathrm{Fe}^{2+}$ $2 \mathrm{p}_{3 / 2}$ at $\sim 710 \mathrm{eV}$ [56] is present on the surface of the steel samples submitted to photoFenton. Iron at its maximally oxidized state-i.e., $\mathrm{Fe}^{3+}$ — can be detected at $~ 715 \mathrm{eV}$ [57] in very low amounts on the surface of the initial stainless steel sample, but most notably on the surface of the samples submitted to photo-Fenton. $\mathrm{Fe}^{2+}$ seems to represent the highest oxidized-state iron contribution. Since the ferrous ions are the main species responsible for electron transfer to the peroxide and persulfate oxidants, their presence on the material's surface confirms the depicted photogeneration of radicals and dye photodegradation mechanism schemes.

\section{Conclusions}

Efficient methods for the degradation of persistent organic compound should make use of commonly available materials, be upscalable, be energy-efficient, and alter the chemical composition of the aqueous environment as little as possible. This work aimed to determine the suitability of using a photo-Fenton process triggered by irradiation with light from the visible spectrum to degrade two model dyes (methylene blue and methylorange) with hydrogen peroxide and potassium persulfate at ambient temperature, without any $\mathrm{pH}$ correction and without stirring. Good photodegradation efficiencies (photodecoloration and mineralization) were achieved by using the operational parameters described in this paper. The photodegradation of the model dyes was achieved at $\mathrm{pH}$ values close to neutral and with considerably lower amounts of peroxide or persulfate than those used in other related studies. Further studies will be performed to assess the photodegradation efficiency of stainless steel in the presence of various interfering anions and cations and for real industrial wastewater effluents.

Author Contributions: Conceptualization, C.C. and I.C.R.; methodology, C.C.; software, I.C.R.; validation, C.C., I.C.R.; formal analysis, C.C., I.C.R., T.M.-P. and A.O.; investigation, C.C., I.C.R., A.O. and T.M.-P.; resources, C.C.; data curation, I.C.R., A.O. and T.M.-P.; writing-original draft preparation, C.C., I.C.R., A.O. and T.M.-P..; writing—review and editing, C.C., I.C.R. and T.M.-P.; visualization, I.C.R. and A.O.; supervision, C.C.; project administration, C.C.; funding acquisition, C.C. All authors have read and agreed to the published version of the manuscript.

Funding: This research received no external funding.

Institutional Review Board Statement: Not applicable.

Informed Consent Statement: Not applicable.

Data Availability Statement: Not applicable.

Acknowledgments: The authors acknowledge the structural funds project PRO-DD (POS-CCE O.2.2.1, ID 123, SMIS 2637, ctr. No 11/2009) for providing the infrastructure used in this work at the CDI Institute of Transilvania University of Brasov.

Conflicts of Interest: The authors declare no conflict of interest.

\section{References}

1. Nidheesh, P.V.; Gandhimathi, R.; Ramesh, S.T. Degradation of dyes from aqueous solution by Fenton processes: A review. Environ. Sci. Pollut. Res. 2013, 20, 2099-2132. [CrossRef]

2. Wang, Z.; Yao, J.; Kralj, M.B.; Dolenc, D.; Trebše, P. Removal of Flotation Collector O-Isopropyl-N-ethylthionocarbamate from Wastewater. Molecules 2021, 26, 6676. [CrossRef] [PubMed]

3. Ahile, U.J.; Wuana, R.; Itodo, A.U.; Sha'Ato, R.; Dantas, R.F. A review on the use of chelating agents as an alternative to promote photo-Fenton at neutral pH: Current trends, knowledge gap and future studies. Sci. Total. Environ. 2020, 710, 134872. [CrossRef] [PubMed]

4. Liang, D.; Li, N.; An, J.; Ma, J.; Wu, Y.; Liu, H. Fenton-based technologies as efficient advanced oxidation processes for microcystin-LR degradation. Sci. Total Environ. 2021, 753, 141809. [CrossRef] [PubMed] 
5. Rekhate, C.V.; Srivastava, J.K. Recent advances in ozone-based advanced oxidation processes for treatment of wastewater- A review. Chem. Eng. J. Adv. 2020, 3, 100031. [CrossRef]

6. Oturan, N.; Oturan, M.A. Chapter 8-Electro-Fenton Process: Background, New Developments, and Applications. In Electrochemical Water and Wastewater Treatment; Matínez-Huitle, C.A., Rodrigo, M.A., Scialdone, O., Eds.; Butter-worth-Heinemann: Oxford, UK, 2018; pp. 193-221. ISBN 9780128131602. [CrossRef]

7. O'Dowd, K.; Pillai, S.C. Photo-Fenton disinfection at near neutral pH: Process, parameter optimization and recent advances. J. Environ. Chem. Eng. 2020, 8, 104063. [CrossRef]

8. Maroudas, A.; Pandis, P.K.; Chatzopoulou, A.; Davellas, L.-R.; Sourkouni, G.; Argirusis, C. Synergetic decolorization of azo dyes using ultrasounds, photocatalysis and photo-fenton reaction. Ultrason. Sonochem. 2021, 71, 105367. [CrossRef]

9. Thiruvenkatachari, R.; Vigneswaran, S.; Naidu, R. Permeable reactive barrier for groundwater remediation. J. Ind. Eng. Chem. 2008, 14, 145-156. [CrossRef]

10. Rezaei, F.; Vione, D. Effect of $\mathrm{pH}$ on Zero Valent Iron Performance in Heterogeneous Fenton and Fenton-Like Processes: A Review. Molecules 2018, 23, 3127. [CrossRef]

11. Thomas, N.; Dionysiou, D.D.; Pillai, S.C. Heterogeneous Fenton catalysts: A review of recent advances. J. Hazard. Mater. 2021, 404, 124082. [CrossRef] [PubMed]

12. Raji, M.; Mirbagheri, S.A.; Ye, F.; Dutta, J. Nano zero-valent iron on activated carbon cloth support as Fenton-like catalyst for efficient color and COD removal from melanoidin wastewater. Chemosphere 2021, 263, 127945. [CrossRef]

13. Minella, M.; Sappa, E.; Hanna, K.; Barsotti, F.; Maurino, V.; Minero, C.; Vione, D. Considerable Fenton and photo-Fenton reactivity of passivated zero-valent iron. RSC Adv. 2016, 6, 86752-86761. [CrossRef]

14. Li, S.; Hua, T.; Li, F.; Zhou, Q. Bio-electro-Fenton systems for sustainable wastewater treatment: Mechanisms, novel configurations, recent advances, LCA and challenges. An updated review. J. Chem. Technol. Biotechnol. 2020, 95, 2083-2097. [CrossRef]

15. Ganiyu, S.O.; Zhou, M.; Martínez-Huitle, C.A. Heterogeneous electro-Fenton and photoelectro-Fenton processes: A critical review of fundamental principles and application for water/wastewater treatment. Appl. Catal. B Environ. 2018, 235, 103-129. [CrossRef]

16. Minella, M.; Bertinetti, S.; Hanna, K.; Minero, C.; Vione, D. Degradation of ibuprofen and phenol with a Fenton-like process triggered by zero-valent iron (ZVI-Fenton). Environ. Res. 2019, 179, 108750. [CrossRef]

17. Evgenidou, E.; Konstantinou, I.; Fytianos, K.; Poulios, I. Oxidation of two organophosphorous insecticides by the photo-assisted Fenton reaction. Water Res. 2007, 41, 2015-2027. [CrossRef] [PubMed]

18. Badawy, M.; Ghaly, M.Y.; Gad-Allah, T.A. Advanced oxidation processes for the removal of organophosphorus pesticides from wastewater. Desalination 2006, 194, 166-175. [CrossRef]

19. Hamd, W.S.; Dutta, J. Heterogeneous photo-Fenton reaction and its enhancement upon addition of chelating agents. In Nanomaterials for the Detection and Removal of Wastewater Pollutants; Bonelli, B., Freyria, F.S., Rossetti, I., Sethi, R., Eds.; Elsevier: Amsterdam, The Netherlands, 2020; pp. 303-330.

20. Xiong, X.; Sun, Y.; Sun, B.; Song, W.; Sun, J.; Gao, N.; Qiao, J.; Guan, X. Enhancement of the advanced Fenton process by weak magnetic field for the degradation of 4-nitrophenol. RSC Adv. 2015, 5, 13357-13365. [CrossRef]

21. Namkung, K.C.; Burgess, A.E.; Bremner, D.H. A Fenton-like Oxidation Process Using Corrosion of Iron Metal Sheet Surfaces in the Presence of Hydrogen Peroxide: A Batch Process Study Using Model Pollutants. Environ. Technol. 2005, 26, 341-352. [CrossRef]

22. Loloei, M.; Rezaee, A. Decolorization of methylene blue by the electro-Fenton process using stainless steel mesh electrodes. Int. J. Environ. Health Eng. 2016, 5, 27. [CrossRef]

23. Untea, I.; Orbeci, C.; Stanescu, R.; Segneanu, A.E.; Craciun, M.E. A new photo-fenton procedure applied in oxidative degradation of organic compounds from wastewater. Environ. Eng. Manag. J. 2012, 11, 141-146. [CrossRef]

24. Di Cesare, A.; De Carluccio, M.; Eckert, E.M.; Fontaneto, D.; Fiorentino, A.; Corno, G.; Prete, P.; Cucciniello, R.; Proto, A.; Rizzo, L. Combination of flow cytometry and molecular analysis to monitor the effect of UVC $/ \mathrm{H}_{2} \mathrm{O}_{2}$ vs UVC/ $\mathrm{H}_{2} \mathrm{O}_{2} / \mathrm{Cu}$-IDS processes on pathogens and antibiotic resistant genes in secondary wastewater effluents. Water Res. 2020, 184, 116194. [CrossRef]

25. Silva, G.D.; Marson, E.O.; Batista, L.L.; Ueira-Vieira, C.; Starling, M.C.V.; Trovó, A.G. Contrasting the performance of photo-Fenton at neutral $\mathrm{pH}$ in the presence of different organic iron-complexes using hydrogen peroxide or persulfate as oxidants for naproxen degradation and removal of antimicrobial activity. Process. Saf. Environ. Prot. 2021, 147, 798-807. [CrossRef]

26. O'Dell, J.W. The Determination of Chemical Oxygen Demand by Semi-Automated Colorimetry; Elsevier: Amsterdam, The Netherlands, 1996; pp. 509-521.

27. Gernjak, W.; Krutzler, T.; Glaser, A.; Malato, S.; Caceres, J.; Bauer, R.; Fernández-Alba, A. Photo-Fenton treatment of water containing natural phenolic pollutants. Chemosphere 2003, 50, 71-78. [CrossRef]

28. Gibbs, M.M. A simple method for the rapid determination of iron in natural waters. Water Res. 1979, 13, 295-297. [CrossRef]

29. Ahmed, N.; Vione, D.; Rivoira, L.; Carena, L.; Castiglioni, M.; Bruzzoniti, M. A Review on the Degradation of Pollutants by Fenton-Like Systems Based on Zero-Valent Iron and Persulfate: Effects of Reduction Potentials, $\mathrm{pH}$, and Anions Occurring in Waste Waters. Molecules 2021, 26, 4584. [CrossRef] [PubMed]

30. Oh, S.-Y.; Shin, D.-S. Treatment of Diesel-Contaminated Soil by Fenton and Persulfate Oxidation with Zero-Valent Iron. Soil Sediment Contam. Int. J. 2013, 23, 180-193. [CrossRef] 
31. De la Cruz, N.; Gimenez, J.; Esplugas, S.; Grandjean, D.; de Alencastro, L.; Pulgarín, C. Degradation of 32 emergent contaminants by UV and neutral photo-fenton in domestic wastewater effluent previously treated by activated sludge. Water Res. 2012, 46, 1947-1957. [CrossRef]

32. Hadjltaief, H.B.; Sdiri, A.; Ltaief, W.; Da Costa, P.; Gálvez, M.E.; Ben Zina, M. Efficient removal of cadmium and 2-chlorophenol in aqueous systems by natural clay: Adsorption and photo-Fenton degradation processes. Comptes Rendus Chim. 2018, 21, 253-262. [CrossRef]

33. Ahmed, Y.; Yaakob, Z.; Akhtar, P. Degradation and mineralization of methylene blue using a heterogeneous photo-Fenton catalyst under visible and solar light irradiation. Catal. Sci. Technol. 2016, 6, 1222-1232. [CrossRef]

34. Gao, Y.; Champagne, P.; Blair, D.; He, O.; Song, T. Activated persulfate by iron-based materials used for refractory organics degradation: A review. Water Sci. Technol. 2020, 81, 853-875. [CrossRef] [PubMed]

35. Ghanbari, F.; Moradi, M.; Manshouri, M. Textile wastewater decolorization by zero valent iron activated peroxymonosulfate: Compared with zero valent copper. J. Environ. Chem. Eng. 2014, 2, 1846-1851. [CrossRef]

36. Liu, Y.; Zhao, Y.; Wang, J. Fenton/Fenton-like processes with in-situ production of hydrogen peroxide/hydroxyl radical for degradation of emerging contaminants: Advances and prospects. J. Hazard. Mater. 2021, 404, 124191. [CrossRef]

37. Su, S.; Liu, Y.; Liu, X.; Jin, W.; Zhao, Y. Transformation pathway and degradation mechanism of methylene blue through $\beta$-FeOOH@GO catalyzed photo-Fenton-like system. Chemosphere 2019, 218, 83-92. [CrossRef] [PubMed]

38. Nguyen, C.H.; Fu, C.-C.; Juang, R.-S. Degradation of methylene blue and methyl orange by palladium-doped $\mathrm{TiO}_{2}$ photocatalysis for water reuse: Efficiency and degradation pathways. J. Clean. Prod. 2018, 202, 413-427. [CrossRef]

39. Wang, Q.; Tian, S.; Ning, P. Degradation Mechanism of Methylene Blue in a Heterogeneous Fenton-like Reaction Catalyzed by Ferrocene. Ind. Eng. Chem. Res. 2014, 53, 643-649. [CrossRef]

40. Elmolla, E.S.; Chaudhuri, M. Effect of Photo-Fenton Operating Conditions on the Performance of Photo-Fenton-SBR Process for Recalcitrant Wastewater Treatment. J. Appl. Sci. 2010, 10, 3236-3242. [CrossRef]

41. Vermilyea, A.W.; Voelker, B.M. Photo-Fenton Reaction at Near Neutral pH. Environ. Sci. Technol. 2009, 43, 6927-6933. [CrossRef]

42. Singh, J.; Chang, Y.-Y.; Koduru, J.R.; Yang, J.-K. Potential degradation of methylene blue (MB) by nano-metallic particles: A kinetic study and possible mechanism of MB degradation. Environ. Eng. Res. 2018, 23, 1-9. [CrossRef]

43. Saleh, R.; Taufik, A. Photo-Fenton degradation of methylene blue in the presence of $\mathrm{Au}-\mathrm{Fe}_{3} \mathrm{O}_{4} /$ graphene composites under UV and visible light at near neutral pH: Effect of coexisting inorganic anion. Environ. Nanotechnol. Monit. Manag. 2019, 11, 100221. [CrossRef]

44. Choquehuanca, A.; Ruiz-Montoya, J.G.; Gómez, A.L.R.-T. Discoloration of methylene blue at neutral pH by heterogeneous photo-Fenton-like reactions using crystalline and amorphous iron oxides. Open Chem. 2021, 19, 1009-1020. [CrossRef]

45. Gil Cortes, J.; Dantas, R.F. Optimization of photo-Fenton to work at neutral pH using NTA-Fe ${ }^{2+}$. Desalin. Water Treat. 2019, 169, 287-293. [CrossRef]

46. Kirchon, A.; Zhang, P.; Li, J.; Joseph, E.A.; Chen, W.; Zhou, H.-C. Effect of Isomorphic Metal Substitution on the Fenton and Photo-Fenton Degradation of Methylene Blue Using Fe-Based Metal-Organic Frameworks. ACS Appl. Mater. Interfaces 2020, 12, 9292-9299. [CrossRef]

47. Lam, F.; Hu, X. A high performance bimetallic catalyst for photo-Fenton oxidation of Orange II over a wide $\mathrm{pH}$ range. Catal. Commun. 2007, 8, 2125-2129. [CrossRef]

48. Devi, L.G.; Kumar, S.G.; Raju, K.S.A.; Rajashekhar, K.E. Photo-Fenton and photo-Fenton-like processes for the degradation of methyl orange in aqueous medium: Influence of oxidation states of iron. Chem. Pap. 2010, 64, 378-385. [CrossRef]

49. Devi, L.G.; Srinivas, M.; ArunaKumari, M. Heterogeneous advanced photo- Fenton process using peroxymonosulfate and peroxydisulfate in presence of zero valent metallic iron: A comparative study with hydrogen peroxide photo-Fenton process. $J$. Water Process Eng. 2016, 13, 117-126. [CrossRef]

50. Kočanová, V.; Dušek, L. Electrochemical dissolution of steel as a typical catalyst for electro-Fenton oxidation. Monatshefte Chem Chem. Mon. 2016, 147, 935-941. [CrossRef] [PubMed]

51. Huang, L.-F.; Hutchison, M.J.; Santucci, J.R.J.; Scully, J.R.; Rondinelli, J.M. Improved Electrochemical Phase Diagrams from Theory and Experiment: The Ni-Water System and Its Complex Compounds. J. Phys. Chem. C 2017, 121, 9782-9789. [CrossRef]

52. Buerge, I.J.; Hug, S.J. Kinetics and pH Dependence of Chromium(VI) Reduction by Iron(II). Environ. Sci. Technol. 1997, 31, 1426-1432. [CrossRef]

53. Mahringer, D.; Polenz, C.; El-Athman, F. Stabilization of Chromium (VI) in the Presence of Iron (II): Method Development and Validation. Water 2020, 12, 924. [CrossRef]

54. Ohmi, T. Formation of chromium oxide on 316L austenitic stainless steel. J. Vac. Sci. Technol. A 1996, 14, 2505-2510. [CrossRef]

55. Huttenlochner, K.; Müller-Renno, C.; Ziegler, C.; Merz, R.; Merz, B.; Kopnarski, M.; Chodorski, J.; Schlegel, C.; Ulber, R. Removing biofilms from stainless steel without changing surface properties relevant for bacterial attachment. Biointerphases 2017, 12, $02 \mathrm{C} 404$. [CrossRef] [PubMed]

56. Li, P.; Jiang, E.Y.; Bai, H.L. Fabrication of ultrathin epitaxial $\gamma-\mathrm{Fe}_{2} \mathrm{O}_{3}$ films by reactive sputtering. J. Phys. D Appl. Phys. 2011, 44, 075003. [CrossRef]

57. Wu, H.; Gao, G.; Zhou, X.; Zhang, Y.; Guo, S. Control on the formation of $\mathrm{Fe}_{3} \mathrm{O}_{4}$ nanoparticles on chemically reduced graphene oxide surfaces. CrystEngComm 2012, 14, 499-504. [CrossRef] 